\title{
Gold thread acupuncture for hemifacial spasm
}

Seungwon Kwon, MD, PhD, and Gyeongmuk Kim, MD

Neurology ${ }^{\circledR}$ 2018;91:185-186. doi:10.1212/WNL.0000000000005868

\section{Correspondence}

Dr. Kwon

kkokkottung@hanmail.net

Figure $1 \mathrm{MRI}$ maximum intensity projection and multiplanar reconstruction angiography

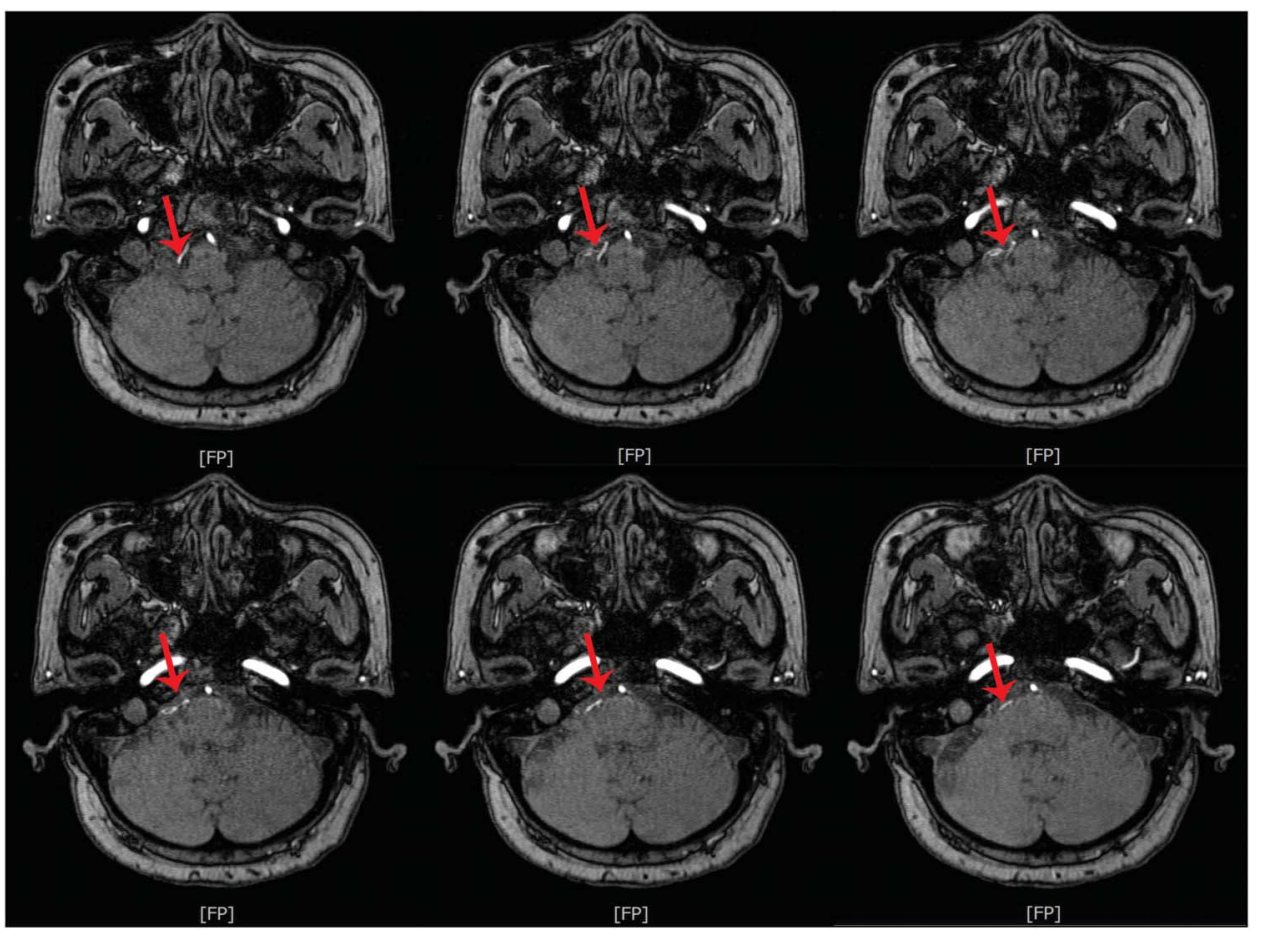

Right 7th and 8th nerve complex root exit zone was compressed by right posterior inferior cerebellar artery (red arrows).

A 73-year-old woman presented with a right hemifacial spasm that started approximately 24 years ago. After this first occurrence, she underwent gold thread acupuncture and microvascular decompression. She visited our department when the symptoms recurred. Brain MRI confirmed vascular compression of the right 7 th and 8th nerve complex root exit zone by the posterior inferior cerebellar artery (figure 1). In addition, the T1 sagittal view showed multiple spotty low signals with a distinct border confined to the right facial region where the gold thread acupuncture was performed 24 years ago (figure 2).

\section{Author contributions}

S. Kwon: study concept and design, acquisition of data, study supervision. G. Kim: acquisition of data.

\section{Study funding}

No targeted funding reported.

\section{Disclosure}

The authors report no disclosures relevant to the manuscript. Go to Neurology.org/N for full disclosures. 

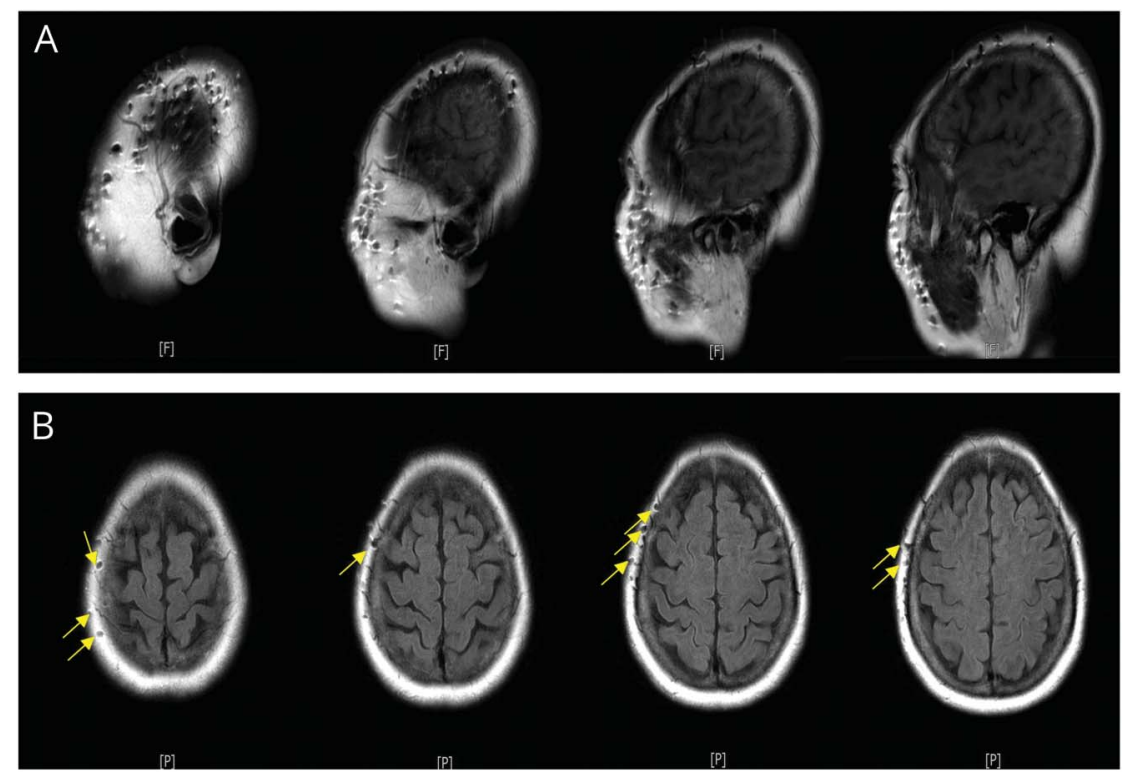

T1 sagittal views $(A)$ and T2 fluid-attenuated inversion recovery axial views (B) indicate gold thread acupunctures. Multiple spotty low signals (yellow arrows) with a distinct border confined to the right facial region where the gold thread acupuncture was performed 24 years ago are seen.

\section{Committed to Making a Difference: 2019 American Academy of Neurology Research Program}

The American Academy of Neurology (AAN) is committed to making a profound difference in the lives of researchers, in turn making a difference in the lives of patients with brain disease. The ambitious 2019 AAN Research Program offers opportunities ranging from $\$ 130,000$ to $\$ 450,000$ and designed for all types of research across all career levels and discovery stages. Pave your own pathway to patient care by applying for one of the opportunities by the October 1, 2018, deadline.

Visit AAN.com/view/ResearchProgram today.

\section{Share Your Artistic Expressions in Neurology 'Visions'}

AAN members are urged to submit medically or scientifically related artistic images, such as photographs, photomicrographs, and paintings, to the "Visions" section of Neurology ${ }^{\oplus}$. These images are creative in nature, rather than the medically instructive images published in the NeuroImages section. The image or series of up to six images may be black and white or color and must fit into one published journal page. Accompanying description should be 100 words or less; the title should be a maximum of 96 characters including spaces and punctuation.

Please access the Author Center at NPub.org/authors for full submission information. 


\section{Neurology}

\section{Gold thread acupuncture for hemifacial spasm \\ Seungwon Kwon and Gyeongmuk Kim}

Neurology 2018;91;185-186

DOI 10.1212/WNL.0000000000005868

This information is current as of July 23, 2018

\section{Updated Information \& Services}

\section{Subspecialty Collections}

Permissions \& Licensing

Reprints including high resolution figures, can be found at: http://n.neurology.org/content/91/4/185.full

This article, along with others on similar topics, appears in the following collection(s):

\section{Blepharospasm}

http://n.neurology.org/cgi/collection/blepharospasm

Clinical neurology examination

http://n.neurology.org/cgi/collection/clinical_neurology_examination

Clinical neurology history

http://n.neurology.org/cgi/collection/clinical_neurology_history MRI

http://n.neurology.org/cgi/collection/mri

Information about reproducing this article in parts (figures,tables) or in its entirety can be found online at:

http://www.neurology.org/about/about_the_journal\#permissions

Information about ordering reprints can be found online:

http://n.neurology.org/subscribers/advertise

Neurology ${ }^{\circledR}$ is the official journal of the American Academy of Neurology. Published continuously since 1951, it is now a weekly with 48 issues per year. Copyright (O) 2018 American Academy of Neurology. All rights reserved. Print ISSN: 0028-3878. Online ISSN: 1526-632X.

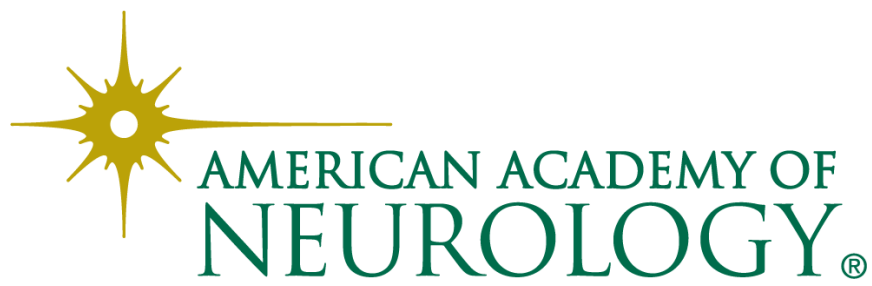

